\title{
TURISMO, TERRITÓRIO E URBANIZAÇÃO: UMA REANÁLISE DO CASO DO MUNICÍPIO DE ANGRA DOS REIS E DA REGIÃO TURÍSTICA DA COSTA VERDE (RJ)
}

\author{
TOURISM, TERRITORY AND URBANIZATION: A NEW ANALYSIS OF THE CASE OF ANGRA DOS REIS AND THE \\ TOURISTIC REGION OF COSTA VERDE (RJ)
}

\section{RESUMO}

Trata-se neste artigo de uma análise do processo histórico de territorialização do turismo no município de Angra dos Reis, Rio de Janeiro. O objetivo central contido nas páginas a seguir foi apresentar o papel do turismo na organização do município a partir da urbanização turística e seus efeitos na política territorial local. Em consequência, se revisitou alguns problemas sociais derivados da instalação do turismo, como a criação de enclaves territoriais, a segregação socioespacial e a privatização dos espaços públicos. Os resultados derivaram de farta e contínua análise da legislação municipal em relação às observações empíricas sobre a prática do turismo em Angra dos Reis nos últimos dez anos.

Palavras-chave: turismo; território; urbanização; política territorial; Angra dos Reis-RJ.

\section{ABSTRACT}

This article deals with an analysis of the historical process of territorialisation of tourism in Angra dos Reis, Rio de Janeiro. The main goal was to present the role of tourism in the organization of Angra dos Reis from the perspective of tourism urbanization and its effects on local territorial policies. As a consequence, some social problems arising from the installation of tourism, such as the creation of territorial enclaves, socio-spatial segregation and the privatization of public spaces, were revisited. The results derived from a large and continuous analysis of the municipal legislation in relation to empirical observations on the practice of tourism in Angra dos Reis in the last ten years.

Keywords: tourism; territory; urbanization; territorial policies; Angra dos Reis-RJ.
Marcos Paulo Ferreira de Góis ${ }^{a}$

${ }^{a}$ Universidade Federal Fluminense (UFF), Niterói, RJ, Brasil

DOI: $10.12957 /$ geouerj.2020.33263

Correpondência: marcosgois@id.uff.br

Recebido em: 20 mar. 2018

Revisado em: 6 jun. 2020

Aceito em: 6 out.2020 


\section{INTRODUÇÃO}

É recorrente apontar que a disseminação do turismo ocorreu após o fim da segunda grande guerra a partir da sua popularização decorrente da abertura das fronteiras nacionais, da regulação dos trâmites e dos protocolos de viagem internacional, da redução do espaço-tempo de viagem, das melhorias alcançadas nos direitos sociais e a criação de mecanismos de conexão entre áreas com o advento de meios de comunicação e de transporte mais eficientes (LANCI DA SILVA, 2004). A importância da atividade turística no mundo atual pode ser observada no seu alcance econômico, absorvendo cerca de $10 \%$ do valor total do Produto Interno Bruto (PIB) de todos os países em 2016, cerca de 7,6 trilhões de dólares, segundo dados da World Travel \& Tourism Council.

Assim como o interesse pelas atividades econômicas ligadas aos setores agrícolas e industriais adquirem centralidade nas pesquisas geográficas, o turismo, enquanto atividade que consome e produz espaços, aparece como um fenômeno recorrente na geografia. São diversas as tentativas de delimitação de um campo para a geografia do turismo (PEARCE, 1979; BRITTON, 1991; WILLIAMS, 1998; HALL \& PAGE, 1999; HALL, 2005) e ainda mais variadas as investidas sobre os conceitos e categorias que demonstrariam esta relação (RODRIGUES, 1997; WILLIAMS \& LEW, 1998; CRUZ, 2000; CASTROGIOVANNI, 2003). Cabe assinalar neste breve artigo a relevância e a pluralidade de abordagens, que não se limitam apenas ao caráter econômico do turismo, mas que fornecem caminhos para questões políticas e culturais de grande relevância para a gestão do território.

A união entre turismo e território pode ser encontrada por diferentes vieses. A intenção é buscar uma rota própria que nos permita apresentar uma proposta de interpretação sobre a apropriação do espaço pelo turismo a partir de um caso. $O$ objetivo central contido nas páginas a seguir foi apresentar o papel do turismo na organização territorial do município de Angra dos Reis, localizado na região da Costa Verde Fluminense (figura 1) a partir da urbanização e de seus efeitos na consecução de políticas territoriais. Observou-se, ainda, as áreas relacionadas ao turismo, incluindo as suas diferentes modalidades a partir de três casos presentes no território angrense: o dos resorts de alto luxo, o das praias acessíveis próximas aos núcleos urbanos e o das ilhas, especialmente o da Ilha Grande. O recorte temporal abarca as primeiras iniciativas turísticas lançadas a partir dos anos 1940, no marco da abertura dos primeiros trechos rodoviários que ligariam Angra e Paraty à metrópole carioca, até o início dos anos 1990, com a introdução de novas diretrizes políticas municipais.

Em relação ao método, a pesquisa se construiu sobre uma reflexão acerca do território e dos processos de ocupação do espaço pelo turismo, adotando uma perspectiva crítica sobre o turismo como atividade indutora de tais processos. Nesse sentido, a reflexão se estruturou a partir da construção de um arcabouço histórico-regional consolidado sobre uma base de dados sobre as leis de uso do solo, os planos de urbanização, os projetos de loteamento e as ações de comercialização de "lugares do turismo". As análises envolveram 
exames qualitativos dos textos e das imagens disponíveis, incluindo acervos hemerográficos, iconográficos, cartográficos e legislatórios do município, e quando necessário, da região da Costa Verde. O material de fontes secundárias foi ainda correlacionado aos dados obtidos durante um longo período de observações empíricas iniciada no ano de 2008. Assim, trata-se de uma pesquisa de caráter temporal diacrônico e geograficamente referida a um município em seu contexto regional.

Figura 1. Mapa de localização do município de Angra dos Reis. Fonte: elaboração própria

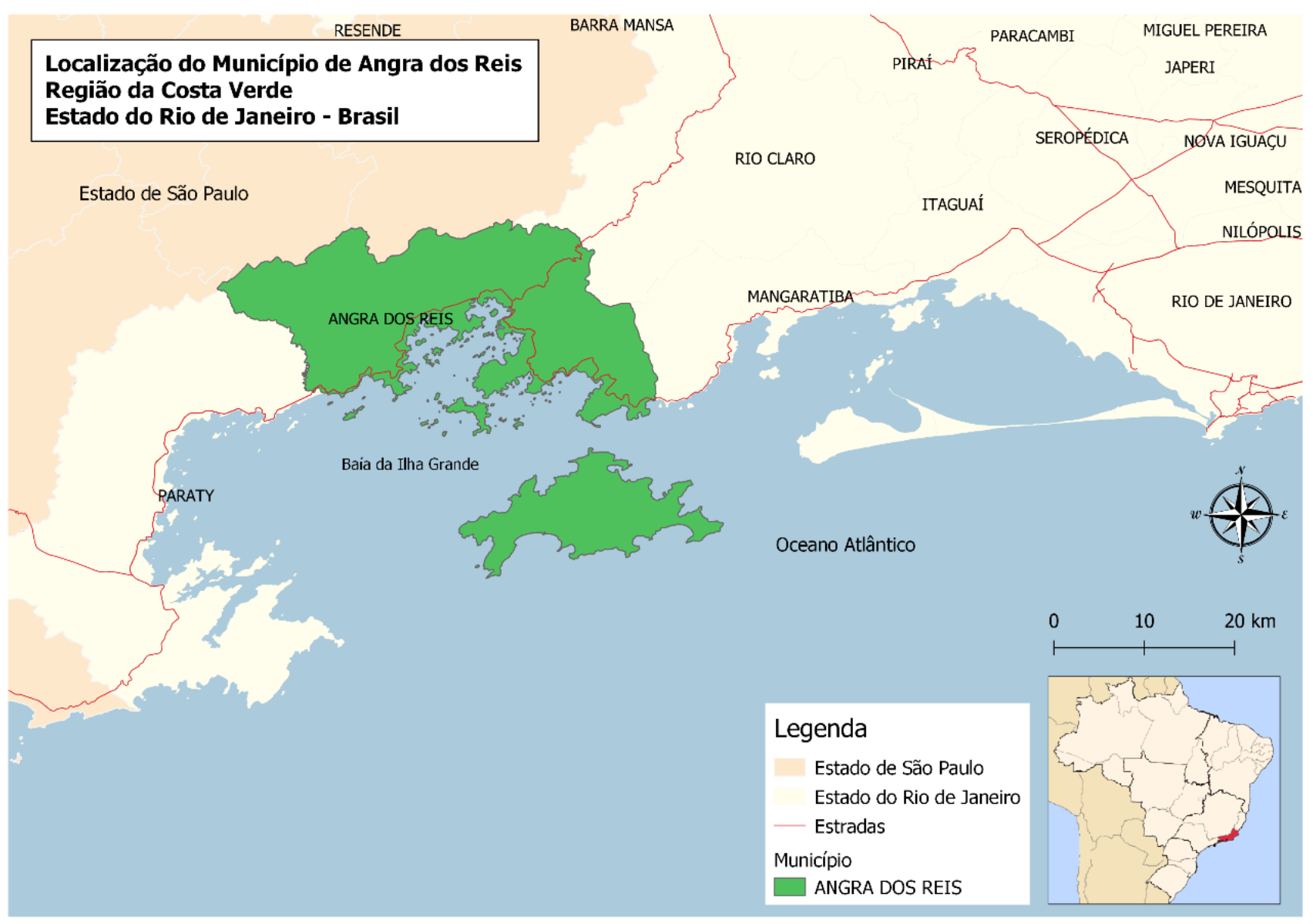

Parte-se de uma análise que vê o fenômeno turístico como um processo de territorialização, ou seja, a transformação nos usos do solo por uma atividade social que produz materialidades novas, desenvolvidas por uma lógica específica, que visa controlar este espaço ao influenciar as práticas sociais e as suas representações. A geografia do turismo pode ser encontrada exatamente na associação entre territorialização e urbanização, sendo a segunda o meio ou o instrumento de realização da primeira. Será sobre esse processo aplicado ao caso de Angra dos Reis que nos ocuparemos nas próximas páginas, observando, na sequência, o fundamento teórico da reflexão proposta no artigo, o processo de territorialização associado ao turismo que se 
desenvolveu em Angra dos Reis e na Costa Verde e, por fim, as características sociais e geográficas desse processo envolvidas com o local mas também articuladas ao contexto regional.

\section{Abordagens sobre o território no estudo do fenômeno turístico}

O interesse dos geógrafos sobre o turismo é bastante diversificado e se apoia em propostas teóricometodológicas razoavelmente distintas, ainda que prevaleça uma abordagem direcionada ao entendimento da produção do espaço pelo turismo. Em relação ao território, os geógrafos estudiosos do turismo se dedicaram, em geral, ao entendimento das políticas estatais de gestão e organização do espaço turístico, essa preocupação se tornou inclusive uma tradição nos estudos sobre turismo na geografia (CRUZ, 2000). Recentemente, o papel de outros atores no desenvolvimento do turismo e na transformação do território através do turismo tem sido realçado. Esse movimento vai ao encontro do campo reflexivo instaurado sobre o conceito de território, em sua recente revitalização dentro da perspectiva da geografia política e da geopolítica. Nesse sentido, há uma visão mais abrangente do conceito, envolvendo uma pluralidade de agentes sociais e o território, não visto mais como apenas um receptáculo ou substrato material estável ou como campo exclusivo de atuação do Estado (COLES, DUVAL \& HALL, 2005).

Dentro de uma perspectiva materialista, o território aparece como um recurso, algo a ser apropriado e utilizado por um grupo como meio de transformação do espaço. Neste sentido, o turismo aparece como uma atividade fortemente territorializada. Isto porque os recursos territorialmente localizados se tornam cruciais para o estabelecimento da atividade turística. Por se tratar de uma atividade que "depende" dos atributos territoriais, o turismo necessita para sua efetivação econômica de sua localização (STORPER, 1994), de elementos singulares que compõem o seu sítio e da proximidade com núcleos emissores (a sua posição relativa). Além disso, conhecer e, nesse caso, mapear tais recursos territoriais é uma estratégia fundamental, seja ela desenvolvida em políticas estatais, seja como mecanismo de planejamento de agentes fundiários, imobiliários e turísticos.

Obviamente, a configuração territorial dos lugares turísticos não é, por si só, responsável pela atração de visitantes, isto depende também dos valores que são atribuídos aos recursos territoriais pelos visitantes, sua valorização como imagem do território. Por isso os atributos territoriais são muito importantes para o turismo. Eles são fatores de diferenciação em relação a outras localidades, dentro de um cenário contemporâneo de grande competitividade entre lugares (FONSECA, 2005). Tais imagens dialogam com públicos distintos e, portanto, com práticas distintas, como vemos no caso de Angra dos Reis, onde o turismo veranista presente nos resorts e ilhas do município se intercala com o turismo internacional e com o turismo de final de semana dos moradores da zona oeste da cidade do Rio de Janeiro. Cada tipo de imagem e de prática 
está, portanto, relacionado a uma localização (e sua acessibilidade) e a um conjunto de características territoriais.

Dentro de outra perspectiva, o território é também um espaço de disputas, no qual há divergências quanto ao seu uso, ocupação e exploração. Assim, a territorialização aparece como um processo que decorre ao longo do tempo, envolvendo diferentes atores sociais, os quais demarcam o espaço com as suas referências materiais e simbólicas. $O$ turismo é uma atividade que se apropria de áreas, especialmente ao utilizar recursos territoriais como mecanismos que criam barreiras a outras formas de ocupação. No limite, as atividades turísticas criam enclaves territoriais, zonas apartadas da dinâmica cotidiana de cidades, no que os resorts são exemplares. Em virtude disso, as transformações promovidas pelo turismo são usualmente comparadas ao consumo do espaço pela indústria (CARA, 1996), o que evidencia a dificuldade em se estabelecer uma explicação original sobre o fenômeno dentro de suas especificidades geográficas.

As transformações advindas do turismo possuem uma repercussão espacial que combina dois processos complementares: a produção material dos lugares e a construção (apropriação, valorização) de símbolos sociais conexos aos lugares. Nesta direção trava-se uma luta pelo espaço e pelos seus usos e significados sociais. Trata-se de um conflito pelo acesso, pelo uso público de tais espaços, como evidencia Irene Ribeiro (2017) em sua dissertação sobre Angra dos Reis. Os conflitos aparecem a partir do encontro de duas lógicas distintas, entre o ritmo cotidiano dos habitantes e o ritmo intenso e acelerado do consumo turístico que afeta as áreas sazonalmente. Os territórios do turismo são, assim, tomados por uma superposição de intenções, as quais se referem a estas duas dimensões fundamentais: a materialidade dos espaços apropriados e os seus significados sociais para a população. O território como espaço de disputas se desdobra também em um território como área sob o controle de um grupo. A territorialidade humana, como forma de exercer o domínio e o controle de uma porção de terra (SACK, 1983), controlando também os comportamentos e as práticas daqueles que entram em seus limites, é um aspecto que não deveria ser ignorado quando se fala do turismo.

As relações sociais de poder estabelecidas através do turismo ou do turismo em relação a outras atividades fazem parte de um processo, o qual poderia ser denominado de territorialização. No processo de territorialização do turismo outras atividades e representações sociais são destorcidas ou encobertas, o que nos leva a afirmar que o turismo se territorializa desterritorializando (CORIOLANO, 2006), ao impor sua força e seu impacto sobre os mecanismos sociais precedentes. Isto repercute a discussão levantada por Rogério Haesbaert (2004) em relação ao processo T-D-R (territorialização-desterritorialização-reterritorialização), especialmente em seus aspectos concretos e simbólicos de apropriação do espaço por um grupo social. É importante afirmar, no entanto, que esse processo depende do modelo de turismo implantado. Em casos extremos pode haver desterritorialização de comunidades locais tradicionais, atividades produtivas e lógicas de organização do espaço. Nesses casos os agentes do turismo exercem grandes intervenções as políticas 
públicas locais e sobre o mercado de terras, como no caso da região da Costa Verde, onde relatos de grilagem de terras e conflitos violentos aparecem desde os anos 1960 nos jornais. Em outros casos há impactos menores, associados a grupos menos homogêneos e a práticas menos intensivas de apropriação, consolidados por medidas políticas de arrefecimento de conflitos, usuais a partir dos anos 1990 em algumas municipalidades fluminenses. De fato, não se trata de um processo homogêneo e as formas de apropriação do espaço são exemplares nesse sentido.

A discussão sobre a territorialização do turismo se amplia, especialmente quando se tem em conta a diversidade de territorialidades existentes nas localidades turísticas. Portanto, os territórios turísticos se confrontam com territórios outros e mesmo dentro dos territórios turísticos há diferentes territorialidades dos turistas, dos trabalhadores do turismo, dos trabalhadores de outras atividades etc. (KNAFOU, 1996). Notase que territorialidades distintas se entrelaçam em espacialidades e temporalidades híbridas nos territórios do turismo, territórios duais que comportam em um mesmo espaço usos distintos (RODRIGUES, 2006). Nos últimos anos há cada vez mais relatos de tensões adquiridas pelo contato entre a ocupação do espaço pelo turismo e as estratégias de territorialização do crime organizado. Tais ocorrências adicionam alguns ingredientes ao problema dos conflitos a que se alude acima. É nesse contexto, rico em contradições sociais e espaciais, que se encontra a territorialização do turismo no município de Angra dos Reis.

\section{Angra dos Reis, territorialização turística e contradições}

Para tratar de algumas contradições sociais e espaciais relativas ao turismo em Angra dos Reis é necessário reconstruir a territorialização como processo histórico dentro de contexto regional. Nesse sentido, a recuperação de alguns fatos históricos é fundamental.

O tecido urbano do município de Angra dos Reis se limitava até a década de 1940 às atuais ruas do Centro e à vila de Mambucaba, em razão da função portuária vinculada ao comércio de escravos e ao escoamento do café do Vale do Paraíba e da produção local de aguardente e outros derivados da cana-deaçúcar. Porém, este crescimento foi paulatinamente reduzido até chegar às vias da retração e total estagnação da economia local (BERTONCELLO, 1992; MACHADO, 1995; ALVES FILHO, 2004; TRIGUEIRO, 2007; CORRÊA, 2008). A cidade passou então por um rápido processo de esvaziamento demográfico e chegou a perder, inclusive, suas características urbanas, restando à população remanescente (ex-escravos, pequenos comerciantes e trabalhadores das antigas fazendas de café ou dos engenhos de cana) o isolamento nas áreas das fazendas e sítios próximos. Boa parte do casario do século XIX foi abandonado e a paisagem adquiriu um aspecto decadente, efeito do esquecimento e do isolamento da região. 
A retomada do crescimento econômico e urbano do município acompanhou as medidas de intervenção estatal sobre a região da Costa Verde e, de forma abrangente, as ações que visavam a recuperação econômica do território estadual a partir dos anos 1930 e 40. No caso de Angra isto significaria a recuperação da função portuária, a ligação ferroviária e a criação de um cadastro fundiário acompanhado de um plano de urbanização desenhado pelo Departamento de Geografia do governo do estado em parceria com o IBGE. A partir dos anos 1950 observa-se o crescimento demográfico e urbano de Angra dos Reis, ainda que limitado pelas ainda insipientes relações com outras regiões do estado, especialmente com a metrópole fluminense, na época capital do estado da Guanabara, e com o Médio Vale do Rio Paraíba do Sul. O acesso por automóvel até 1970 era somente possível via a atual RJ-155 (Rodovia Saturnino Braga) que alcançava a Rodovia Rio-São Paulo na altura de Barra Mansa. Tal aspecto foi durante trinta anos um obstáculo para o desenvolvimento turístico regional, limitado aos poucos loteadores, grileiros e agentes fundiários interessados por aquelas terras até a década de 1970.

O crescimento urbano associado ao turismo, apesar de ser anterior a década de 1970, somente se constitui em um vetor importante de crescimento urbano a partir de então. Segundo dados do Censo IBGE, entre 1970 e 2010, a população do município de Angra dos Reis quadruplicou, de cerca de 40 mil habitantes para cerca de 160 mil no ano de 2010. Outros empreendimentos tiveram papel importante na organização do território municipal, como as usinas nucleares, o estaleiro holandês Verolme, o terminal petrolífero e a construção da BR-101 e as explicações que concernem ao crescimento demográfico podem ser encontradas nos dados de migração para os períodos de construção de tais ações (ALVES FILHO, 2004). Tais obras provocaram profundas mudanças no território municipal e, neste caso, as alterações mais importantes se deram no desdobramento da fixação desses empreendimentos no território. O município é atualmente caracterizado pela densa ocupação das áreas de encosta e pela evidência dos riscos associados aos desastres sócio-naturais recorrentes na região.

O turismo em Angra dos Reis - e consequentemente em boa parte da Costa Verde - possui algumas diferenças quando comparado a outras modalidades de turismo praticadas no estado do Rio de Janeiro. $\mathrm{O}$ turismo praiano/náutico constituído pelo trinômio sol-céu-mar (RIBEIRO, 2003) que se verifica em Angra dos Reis possui conteúdos diferenciados daqueles encontrados no litoral norte do estado do Rio de Janeiro. Alguns fatores podem ser elencados para explicar as diferentes características de territorialização do turismo em Angra dos Reis:

a) Conexão: a tardia ligação rodoviária com a metrópole carioca representou um obstáculo para a venda de algumas fazendas até 1970, quando o trecho sul da BR-101 é inaugurado. Os trens não transportavam com regularidade passageiros e a ligação náutica era muito difícil e demorada em razão das condições do clima e das variações do tempo no litoral. 
b) Situação geográfica: o município de Angra dos Reis encontra-se enclausurado entre os contrafortes da Serra do Mar e o Oceano Atlântico. Cerca de três quartos da área territorial encontram-se acima da cota $200 \mathrm{~m}$, com trechos de alta declividade intermeados por pequenas planícies em forma de gamboas, nas quais se assentaram a maior parte das habitações. A forma acidentada do relevo condicionou a fragmentada ocupação, formando um arquipélago de pequenas cidades ao longo da costa.

c) Mercado de terras: as fazendas da região começaram a ser adquiridas por grupos empresariais já nos anos 1950, mas a sua ocupação é lenta e decorre da abertura da BR-101 a partir dos anos 1970. Em geral, as áreas da face costeira da BR-101 foram adquiridas legalmente ou griladas para a construção de condomínios de luxo; enquanto que as áreas localizadas nos sertões ficaram disponíveis para a ocupação por meio de posses, voltadas para o crescimento de habitações simples de trabalhadores das obras ocorridas desde a década de 1950 na região.

d) Modelo turístico: Angra dos Reis recebeu um direcionamento de mercado voltado para a promoção de marinas, portos, condomínios e residências de alto luxo, intercaladas com iniciativas de atração de turistas internacionais, como apontado pelo Projeto Turis, que visava promover a ideia de uma nova Côte D’Azur. Neste sentido, o governo local atuou na facilitação da divulgação da imagem paradisíaca e na criação de infraestrutura para os primeiros empreendimentos imobiliários construídos nos anos 1970.

O Estado teve, de fato, um papel significativo na territorialização do turismo em Angra dos Reis. A primeira forma de territorialização do turismo deveu-se em grande medida a duas ações do Estado na viabilização de um projeto desenvolvimentista e de ocupação territorial: em primeiro lugar, a solicitação de um estudo de viabilidade turística - Projeto TURIS - criou uma base para o planejamento do uso do solo na região; em segundo lugar, o plano de ocupação do litoral angrense pelo turismo deu lugar a ação em si, executada através de leis de uso e ocupação do solo, o que privilegiou os empreendimentos imobiliários e urbanos ligados ao turismo.

A primeira resolução estatal foi declarar as áreas dos municípios da Costa Verde como Zona Prioritária para Fins de Reforma Agrária, ainda em 1972. A medida, no entanto, teve um efeito adverso, estimulando a grilagem de terras e a incorporação do solo rural para loteamentos e outros objetivos não afeitos à proposta de reforma. No ano seguinte, o governo federal cria um arranjo burocrático no qual facilitaria ainda mais os investimentos do capital imobiliário-turístico. Ao declarar que “[...] toda área compreendida entre o mar e a distância de até $1 \mathrm{~km}$ após o eixo da rodovia [...] como Zona Prioritária de Interesse Turístico [...]" (CORRÊA, 2008, p.263), o Estado através do Conselho Nacional de Turismo (CNTur) direcionou os seus investimentos para o setor turístico e privilegiou os interesses empresariais e especulativos de membros do setor imobiliário- 
turístico em detrimento de projetos ligados à reforma agrária e aos interesses da população local. Esta ação do Estado acaba por direcionar o processo de ocupação e organização territorial para a estreita faixa litorânea entre a rodovia BR-101 e a baía da llha Grande, privilegiando o uso pelo turismo em relação ao uso pelas comunidades tradicionais - caiçaras, indígenas e quilombolas - que ocupavam (ou voltavam a ocupar) as áreas há décadas (ALVES FILHO, 2004).

O resultado deste conjunto de medidas governamentais foi um intenso processo de especulação fundiária, na forma de um modelo de ocupação do solo que visava antecipar os lucros futuros com a reversão do uso rural do solo para o uso urbano. Esse processo foi corretamente analisado por Paul Singer (1979) como um mecanismo de mercado no qual a "[...] valorização da gleba é antecipada em função de mudanças na estrutura urbana que ainda estão por acontecer [...]" (SINGER, 1979, p. 23). Este modelo geral foi amplamente ratificado por proprietários agrícolas da região que, com a abertura da BR-101 e as promessas de desenvolvimento econômico, mantiveram grandes trechos de terra improdutiva às margens da nova estrada à espera de valorização. Essas terras foram progressivamente incorporadas ao uso urbano, seja através do loteamento realizado pelos antigos proprietários rurais, seja pela incorporação de terras por agentes imobiliários. Os trechos mais bem localizados à beira-mar foram adquiridos para fins de lazer e entretenimento turístico, enquanto que para as áreas localizadas no interior do município os usos urbanos foram diversos.

Na consecução da territorialização do turismo, outro fator importante para a paulatina urbanização do município foi o processo de invasão-sucessão (CORRÊA, 2005), instaurado pela substituição das habitações da população tradicional caiçara por um conjunto de formas e funções urbanas ligadas ao turismo exclusivo. Novos moradores permanentes ou temporários se instalaram nessas áreas e tal mudança na característica do local gerou efeitos sociais e ambientais importantes, como a retificação de canais, a derrubada da mata, a devastação de manguezais e restingas, a expulsão de população caiçara, a supressão de praias e a artificialização e criação de cenários turísticos estranhos ao meio (figura 2).

Figura 2. Comparação de fotos entre a antiga Fazenda Bracuí no início da década de 1970 e o resort Porto Bracuhy em imagem recente. Fonte: http://www.bracuhy.com.br
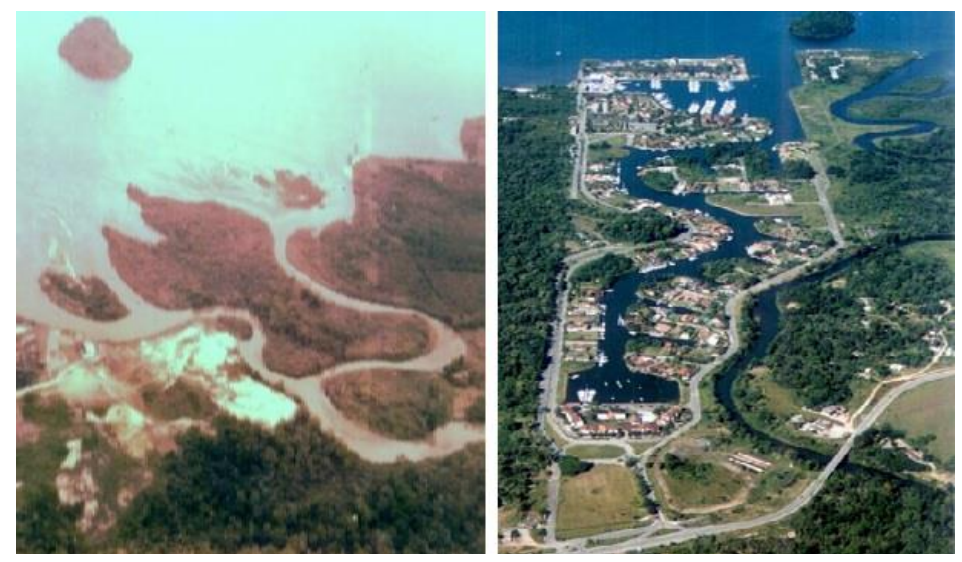
Esta conformação territorial começou a se consolidar ainda na década de 1970, quando as medidas políticas locais tinham pouca relevância na constituição do território e o poder local encontrava muitas dificuldades para estabelecer um marco regulatório que beneficiasse o município (BERTONCELLO, 1992). Dessa forma, a territorialização do turismo foi promovida por medidas centralizadas (alhures) de gestão do território, se apropriando dos recursos territoriais locais para criar uma marca para o turismo. Em muito isso se deve ao fato de que os municípios tinham uma limitada equipe técnica e um corpo de funcionários pequeno para atuar na fiscalização da ocupação do solo.

Os recursos territoriais presentes em Angra dos Reis - "natureza" abundante com a presença de praias, ilhas, floresta etc. - foram fartamente utilizados no intuito de gerar uma marca para a localidade e atrair os fluxos de turistas desejosos de uma localidade idílica e aprazível. O modelo de turismo em resorts, com segundas residências, flats, hotéis de luxo e condomínios com marinas se estabeleceu no continente, contrastando com o modelo turístico da Ilha Grande, direcionado a um público mais amplo e flutuante, além do papel adquirido pelas praias continentais para os moradores do município e para os turistas, em geral, da região metropolitana do Rio de Janeiro (FONSECA \& LOPES-JUNIOR, 2016).

Por ser uma atividade envolvida em interesses tão diversos, o turismo encontra-se profundamente vinculado às medidas de gestão do território e, portanto, é constantemente o objeto de interesse de projetos estatais e investimentos privados que visam o desenvolvimento regional e a valorização das atividades. Em virtude disso, foi acolhida a ideia de tratar apenas de três casos que exemplificam as maneiras pelas quais o turismo se territorializa em dado lugar. São tipos ideais que ajudam a pensar o aspecto geográfico do turismo e a sua ambiguidade: a) o enclave territorial; b) o balneário metropolitano; e c) o refúgio patrimonial. Os casos serão vistos a partir do exame de algumas localidades turísticas de Angra dos Reis - e algumas referências a localidades próximas (figura 3) - realizado desde o ano de 2009. Esta classificação agrupa um conjunto de variáveis, como as materialidades construídas pelo turismo, como hotéis, habitações, pousadas, ruas, marinas etc.; as práticas de turismo, ou seja, o que as pessoas fazem no território do turismo como lazer; o perfil do público frequentador; as representações criadas para os lugares; os recursos territoriais mobilizados na criação da imagem do lugar; e os investimentos e agentes envolvidos.

\section{O enclave territorial e o exemplo dos resorts}

O modelo brasileiro de planejamento do turismo apresentou uma forte correlação entre turistificação e urbanização, de tal forma que o Estado implementou medidas de desenvolvimento urbano e de modernização dos meios de comunicação de forma intensiva ao longo dos anos 1960 e 70, especialmente no litoral brasileiro. As políticas de Estado para o turismo em países emergentes têm se apoiado sobre a 
construção de infraestrutura de comunicação (portos, aeroportos e estradas) e de infraestrutura urbana básica (arruamento, saneamento, iluminação etc.), viabilizando o desenvolvimento do turismo por meio de membros da sociedade organizada, operando na aquisição, parcelamento e venda de lotes ou empreendimentos imobiliários.

Figura 3. Mapa de localização das praias e dos resorts pesquisados no município de Angra dos Reis entre 2009 e 2018 . Fonte: elaboração própria

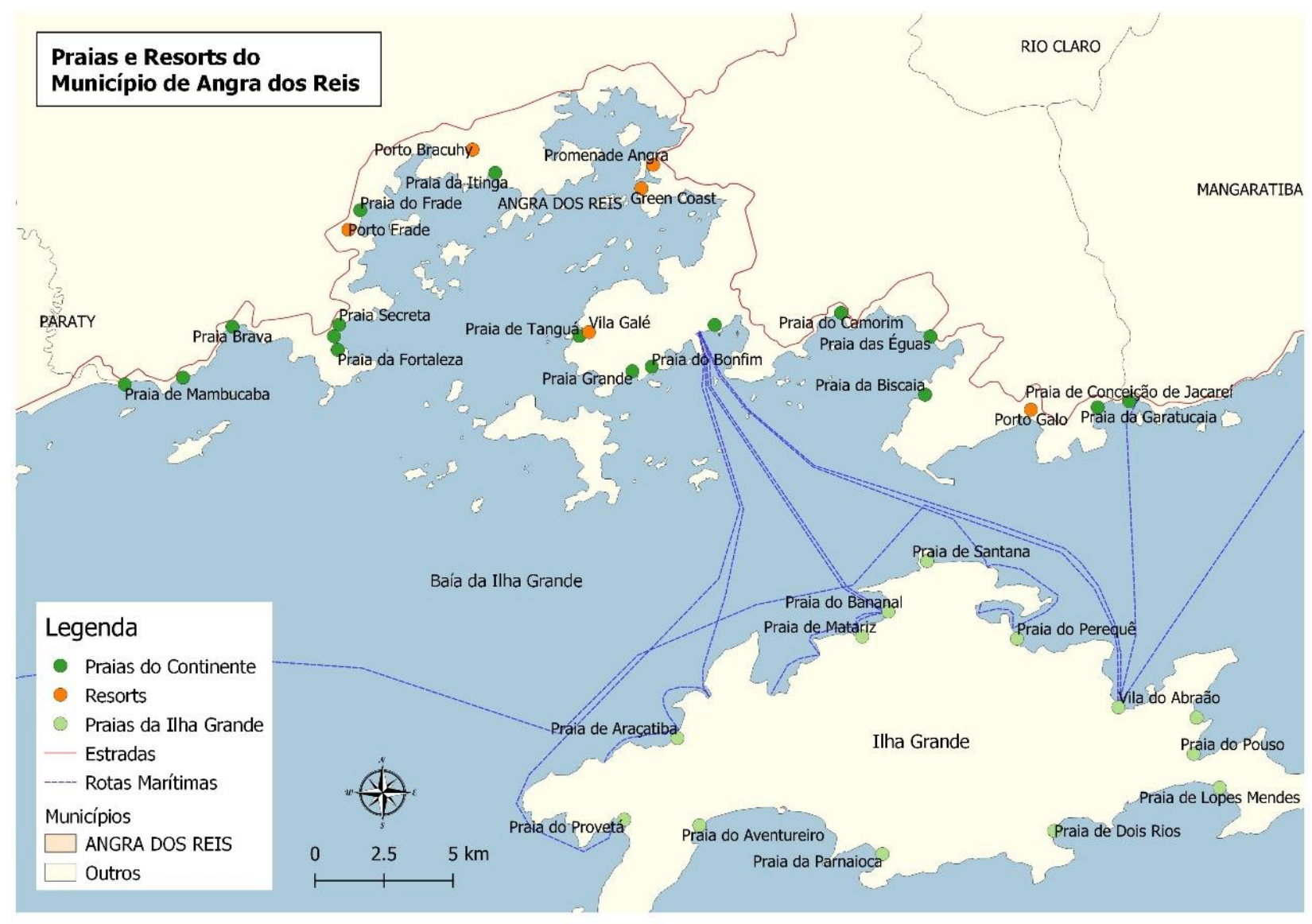

Os resorts derivam, em parte, desse processo no qual os agentes privados constroem grandes empreendimentos imobiliários na forma de condomínios de casas e de apartamentos visando o público de classe média-alta das regiões metropolitanas próximas. No caso de Angra dos Reis se trata de uma elite urbana, geralmente composta por moradores das cidades do Rio de Janeiro e de São Paulo, que adquirem seus imóveis como segunda-residência ou como estância veranista a ser usada, principalmente, nos períodos de férias escolares. Tais resorts se transformaram em estâncias balneárias para uma classe alta emergente a partir dos anos 1990, constituída por políticos, artistas, esportistas e empresários. Estas pessoas se tornam, inclusive, "garotos-propaganda" dos empreendimentos imobiliários, atraindo o interesse de outros clientes. 
A atratividade dos resorts reside, portanto, em um conjunto de amenidades que são compreendidas como elemento de status social. Os resorts possuem como parte de sua estrutura um conjunto de amenidades valorizadas por estes grupos sociais, como áreas de marina, de lazer e de práticas esportivas, funcionários que cuidam da segurança e da limpeza das áreas comuns e dos prédios, estacionamento privativo, acesso às redes de comunicações e sistema interno de monitoramento e segurança. Além disso, apesar da grande variedade arquitetônica e paisagística, estes espaços são delimitados por muros, cercas vivas, arames, telas e guaritas que os separam da vizinhança e que controlam a entrada de pessoas, incluindo o cerceamento do uso dos espaços públicos, como a praia. Em alguns casos, há pequenas aberturas, ou servidões, que permitem o acesso, o que pode ser observado no detalhado trabalho de Ribeiro (2017) sobre as praias de Angra dos Reis.

Em um sentido amplo, o que se observa nesses casos pode ser comparado ao que foi ressaltado por Patrick Mullins (1991) ao propor a ideia de uma urbanização turística como vetor da organização espacial das cidades costeiras australianas. Mullins propõe em seu estudo que a urbanização turística possui uma lógica nova em relação aos outros princípios que desencadeiam o processo de urbanização, isto porque estas cidades são construídas unicamente para o consumo e para o prazer do visitante/veranista. O estudo de Mullins foi sistematicamente adotado por autores brasileiros, que de forma crítica aplicaram e adaptaram suas ideias aos exemplos do país. Os trabalhos de Silva (1997), Luchiari (1998), Fonseca (2005) e Mascarenhas (2005) são precisos ao apresentarem as características principais da urbanização turística no que se refere ao caso brasileiro. De tal forma que podemos apresentar os pontos em que estes autores convergem ao tratarem do fenômeno da urbanização derivada da prevalência da atividade turística:

- o consumo prevalece sobre a atividade produtiva, o que é fortemente caracterizado pela presença de atividades novas, sem aderência ao lugar, como shopping centers, galerias comerciais, redes de fast food e os próprios resorts;

- as cidades turísticas tornam-se objeto do desejo das classes média e alta metropolitana, as quais ocupam sazonalmente as áreas turísticas;

- valorização estética de elementos "típicos" da localidade e criação de mecanismos modernos de transporte, uso e comunicação do/no espaço urbano;

- rápido crescimento econômico associado a um acelerado processo de degradação ambiental e inflação local de caráter sazonal;

- aumento da população e da força de trabalho nos setores de construção civil e de serviços (fluxos migratórios auxiliam e muito este processo); 
- precarização das condições de trabalho e baixa remuneração (ofertas sazonais de empregos mal remunerados);

- forte especulação imobiliária e segregação residencial (auto-segregação e segregação induzida); e

- presença de ativismos sociais e pressão dos moradores sobre o poder público local.

Acredita-se que a configuração territorial de uma cidade turística como Angra dos Reis se deva em grande parte a essa nova realidade materializada através da urbanização turística. Novos fixos são construídos em razão da necessária aparelhagem do território de estruturas capazes de sustentar os fluxos de turistas. Além disso, há a criação de amenidades, frutos da preservação de atributos antigos ou da construção de atributos novos, fundamentais para a atração desses fluxos, e que compõem o escopo de alguns dos projetos urbanísticos locais, como no caso dos resorts. Ainda assim, deve-se ponderar os efeitos locais da territorialização do turismo e da sua manifestação urbana, visto que há condicionamentos locais que não respeitam a alguns pressupostos do modelo.

À título de exemplo, notamos em relato obtido em trabalho de campo, a estratégia de territorialização do espaço por um resort. Nesse caso, a ação foi conduzida por um empresário chamado Carlos Borges, proprietário de resorts em Angra dos Reis e Mangaratiba desde os anos 1970. A primeira iniciativa, a Marina Porto Frade (em Angra), criada na década de 1970, derivou da compra de uma antiga fazenda, visando a produção de um espaço privativo familiar à beira da BR-101 (figura 4). O resort visava um público específico a ser atraído pela oferta de um lazer balneário para toda a família, a qual poderia, em relativo isolamento geográfico, desfrutar de certa exclusividade.

As demandas criadas pelo resort e pelos condomínios aos poucos atraíram uma população de trabalhadores pobres, muitos deles migrantes da região nordeste do país, para a outra parte da antiga fazenda, que não havia sido adquirida pelo empresário, sendo fragmentada em lotes e ficando à mercê de grileiros e posseiros. Para os proprietários tal situação de contraste entre as duas formas urbanas se revelaria um problema para o ordenamento local (figura 5). 
Figura 4: Anúncio de venda de imóveis no Marina Porto Frade. Fonte: O Globo, 02 de Fevereiro de 1978, página 3

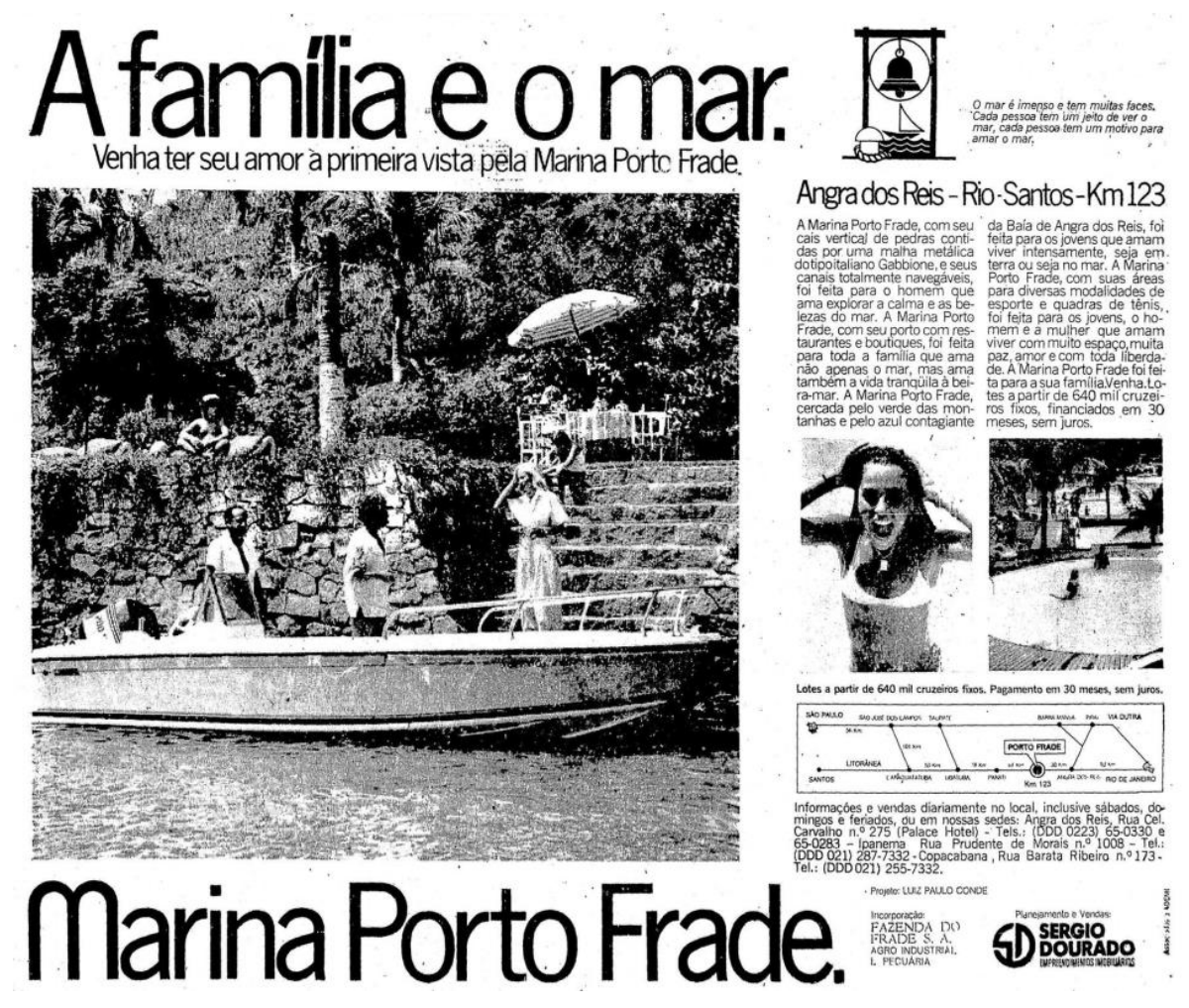

Na aquisição do resort Portobello (em Mangaratiba), nos anos 1980, esta questão seria abordada novamente, prevalecendo, então, a ideia de adquirir todas as fazendas do entorno para o empreendimento e uma "reserva paisagística" que permitisse um significativo isolamento visual em relação ao entorno e a possibilidade de futuras expansões. Atualmente, a reserva paisagística compreende um pequeno safari e uma nova área dedicada à construção de um aeroporto e de uma expansão da antiga marina, sendo um dos espaços mais exclusivos de toda a região.

Em áreas como a do Porto Frade se notam, portanto, algumas das características levantadas por Mullins (1991). A criação de grandes cidades muradas tende até mesmo a criar na sua contraparte, um conjunto residencial urbano precário, composto, em sua maioria, por migrantes e trabalhadores de ocasião, em geral pobres, que voltam para os seus municípios de origem em períodos de baixa temporada no turismo local, atuando, em geral, na produção agrícola. Cria-se um recorte espacial profundo entre duas cidades que são economicamente complementares, mas profundamente diferentes em seus conteúdos sociais, revelando uma simetria perversa, exposta de forma clara no padrão construtivo de suas territorializações. 
Figura 5. Imagem de satélite do Marina Porto Frade (abaixo - amarelo) e do bairro do Frade (acima - vermelho). Fonte: Google Earth, 2019.

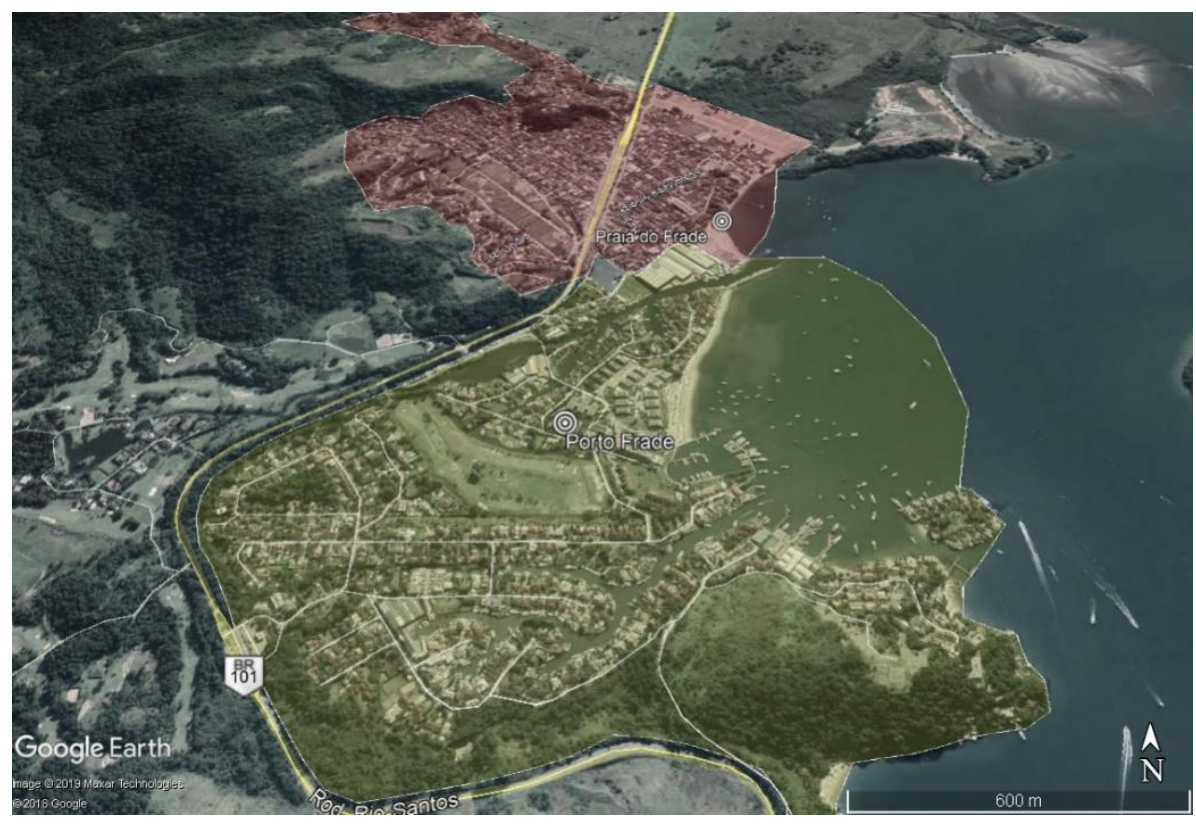

\section{O balneário metropolitano}

O "modelo resort" é aquele que apresenta características paisagísticas mais expressivas devido, especialmente, ao seu caráter planejado e altamente consumidor de espaço. No entanto, a territorialização da atividade turística adquire outras formas que são promovidas por outros agentes sociais e decorrem da sua capacidade de transformar e ocupar o espaço. O turismo de veraneio abarca também o interesse de um público de classe média e baixa, os quais não podem pagar os custos da exclusividade, mas que, ainda assim, valoriza o lazer do tipo balneário associado às praias, ilhas e orlas.

Desde os primórdios da organização política do território fluminense, ainda nos primeiros anos do século XX, as práticas de veraneio eram compreendidas como fatores indutores da economia e da ocupação do território. As primeiras ações estatais para o turismo no interior do estado remetem aos primeiros dias do Estado Novo, na grande área que recobre as atuais regiões da Costa Verde e dos Lagos (PARENTE-RIBEIRO; GÓIS \& SOTRATTI, 2019).

As ações envolviam a criação de hotéis, vilinos e pequenos restaurantes às margens das recémconstruídas estradas. As orlas e os espaços públicos criados visavam atrair visitantes que pudessem comprar terrenos e construir suas casas de veraneio ou pequenos estabelecimentos comerciais. Nesse caso, não seriam os grandes empreendimentos turísticos que dirigiriam a ocupação do espaço, mas as pequenas intervenções orientadas pelo interesse imobiliário local, o que era dirigido por uma perspectiva de antecipação espacial, ou seja, a terra como negócio, como investimento familiar à espera da valorização futura. Para viabilizar tal 
iniciativa foi crucial que se investisse em infraestrutura urbana básica. Os problemas ocasionados pela sua falta eram evidentes entraves para a consolidação de um projeto nacional de modernização do território e para a introdução do país na nova ordem econômica global (BECKER \& EGLER, 1994). Deste cenário emergiram diversas medidas que consolidaram o modelo de desenvolvimento nacional, incluindo o turismo como uma das atividades privilegiadas a partir da década de 1940.

Muitas iniciativas relacionadas ao turismo foram, até a década de 1970, direcionadas regionalmente, a partir de ações localizadas pontualmente em alguns setores do território. Para o Rio de Janeiro o turismo foi, ao mesmo tempo, uma atividade impulsionada pela prática do veraneio e pela perspectiva do crescimento urbano em direção aos litorais ao sul e ao norte da baía de Guanabara, o que se pode afirmar como um vetor balneário para a urbanização (PARENTE-RIBEIRO; GÓIS \& SOTRATTI, 2019).

Desde os primeiros anos da década de 1940 - quando da construção da Rodovia Ernani do Amaral Peixoto, a via litorânea que ligava a capital do estado do Rio à Cabo Frio - havia uma orientação rodoviária ligada à produção de cidades ou à urbanização de cidades existentes. Tais cidades teriam o turismo como elemento orientador do processo de urbanização, o que desencadeou, em alguns casos, aquilo que tratamos como enclaves territoriais. No entanto, há casos em que o turismo não produz necessariamente enclaves, mas territorializações que se encaixam a uma organização urbana prévia ou que reativam cidades e áreas anexas em proveito do uso comum, com a criação de espaços públicos.

A imagem do turismo, especialmente nas cidades-balneárias fluminenses, compreendeu a criação do espaço urbano, de um sistema de loteamento periférico, de roteiros, de paisagens e de vistas. Esse acervo de imagens resulta de uma forma de habitar o litoral que possui grandes relações com o processo de metropolização e com o viés veranista da prática turística no estado. Mais do que isso, esse processo constituiu uma paisagem, ou seja, um conjunto de morfologias, práticas e significados associados ao mar que possui uma memória e que se apresenta como uma forma de habitar o litoral fluminense.

Nos municípios da Costa Verde se observa a presença de muitas casas de veraneio. Em alguns municípios como Mangaratiba, por exemplo, estima-se que metade da população seja flutuante. Em sua maioria são moradores da cidade do Rio de Janeiro que possuem residências secundárias em pequenos condomínios ou bairros que surgiram a partir dos loteamentos realizados nas décadas anteriores. Nesse caso, o lazer nas praias abertas ao público e os passeios para as ilhas da região se tornam a principal atividade para esses veranistas.

Em Angra dos Reis é comum observarmos a presença desse público nas praias, o qual escolhe justamente aquelas praias próximas aos centros dos bairros de Angra dos Reis, especialmente ao longo da Estrada do Contorno e da Ponta Leste, para realizar suas atividades de lazer. Praias como a da Biscaia, a Grande 
e a do Bonfim concentram muitas pessoas nos fins de semana de verão e nos feriados. Em sua maioria, essas pessoas chegam à cidade de carro e se instalam em pousadas e casas de parentes que margeiam a rodovia BR-101 ou o centro histórico de Angra dos Reis.

Em outros casos o que se observa é a vinda de excursões em ônibus fretados, que ocupam os estacionamentos públicos e que privilegiam estadias breves, de no máximo dois ou três dias. Além disso, também são observadas uma grande procura pelos meios de deslocamento entre o continente e as ilhas. Alguns acessam a Ilha Grande por meio de barcos ou da barca que realiza a travessia via Mangaratiba ou Angra dos Reis (figura 6). Em todos os casos, no entanto, o que se observa é o uso intensivo dos lugares e uma brusca mudança dos ritmos sociais e dos impactos sobre o cotidiano da população permanente, tanto em termos econômicos, quanto em termos ambientais.

Figura 6: Foto da barca que faz os trajetos entre Mangaratiba, Ilha Grande e Angra dos Reis. Fonte: autor, 2010

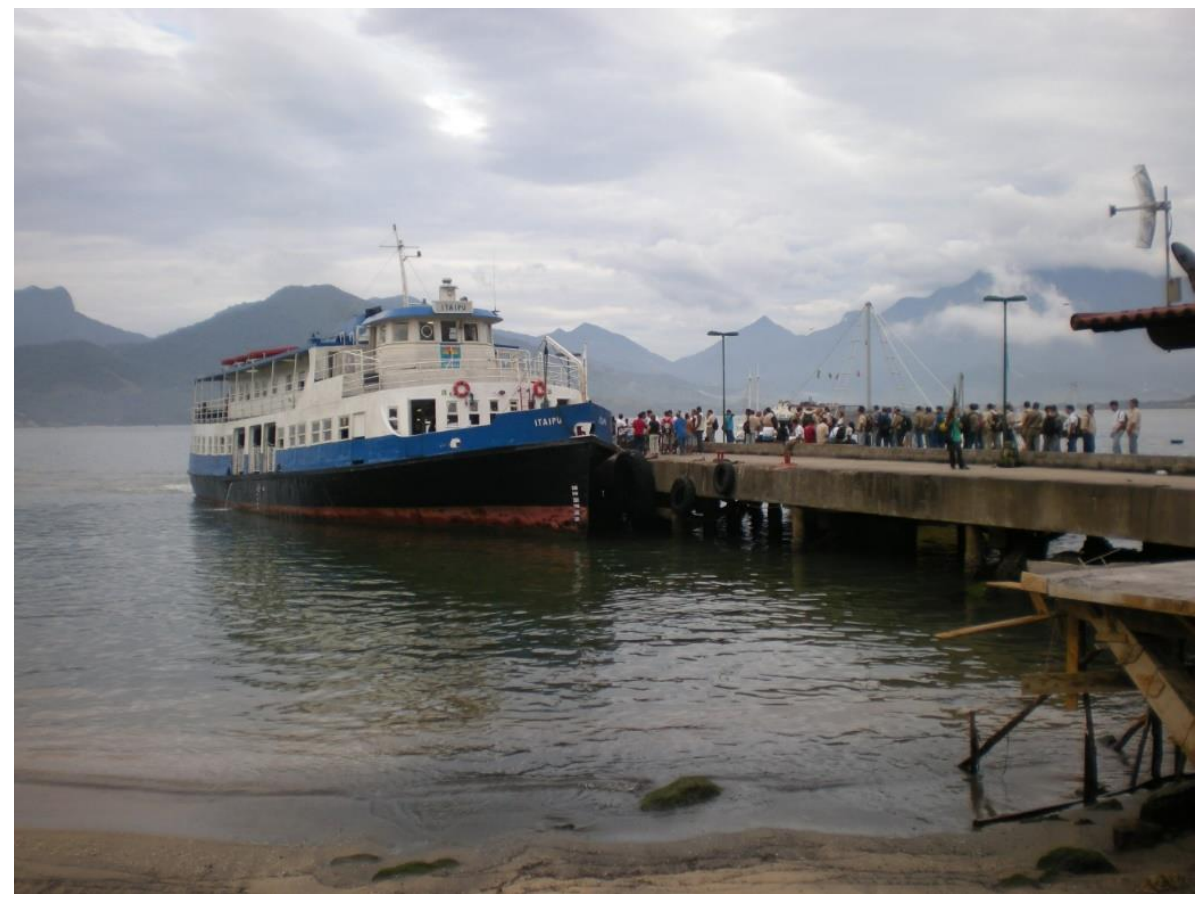

A territorialização dessa forma de turismo é antiga e os traços são menos visíveis ou característicos. Normalmente se associam a processos pretéritos de organização espacial, com a apropriação de terrenos, loteamentos e autoconstrução, como no caso dos condomínios e bairros. São espaços intermeados por hotéis antigos e pequenas pousadas à beira-mar, geralmente dos anos 1970 e 80 . Improvisos arquitetônicos decorrentes da refuncionalização de antigos casarões e fábricas, ruas de comércio varejista, mercados pequenos, padarias, estacionamentos e agências de turismo são marcos da fisionomia de tais praias. 
Não há claramente uma barreira ou qualquer elemento de separação que delimite rigorosamente os usos, mas, ainda assim, a construção dos lotes e das habitações sobre a linha da costa coloca eventuais dificuldades para a circulação (figura 7). Novamente, as servidões precisam ser garantidas por lei para desobstruir acessos e permitir o desenrolar das práticas sociais de veraneio. Nesse aspecto repete-se o problema dos resorts: fecham-se os acessos para tentar se obter um recanto exclusivo e segregado em relação ao entorno. O que muda, no entanto, é a capacidade de se manter a exclusividade, o que é mais claramente observado quando se compara os dois tipos ideais.

Figura 7: Colagem de fotos da Praia da Figueira, com a sinalização da servidão, o caminho de acesso e a praia. Fonte: Elaboração própria. Fotos de 2010
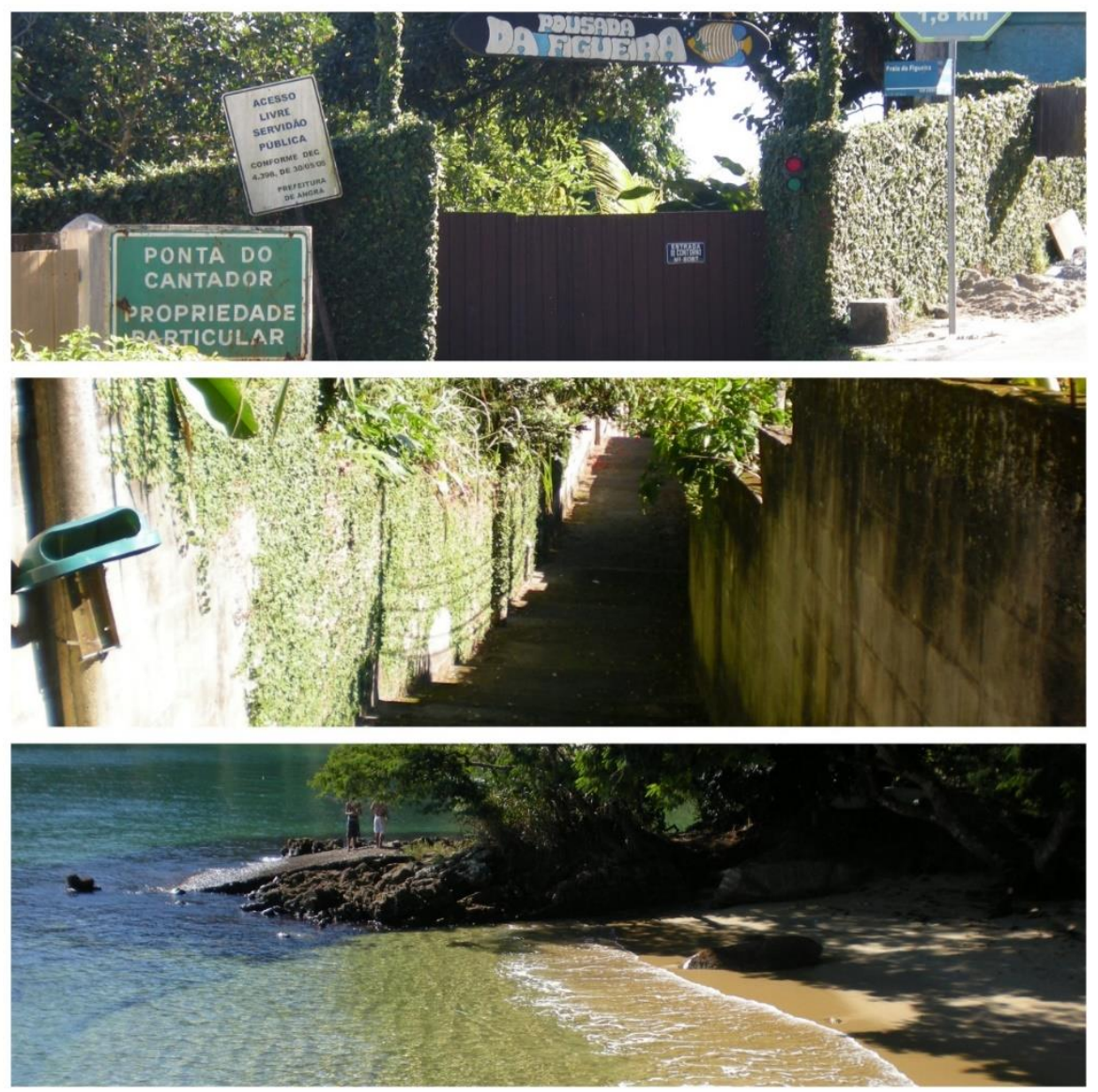

O refúgio patrimonial da Ilha Grande

As estratégias comentadas acima estão implicadas ao modelo de desenvolvimento adotado pelo país no período do pós-guerra. O modelo desenvolvimentista adotado pelos países de economia atrasada foi a forma encontrada pelo Estado brasileiro de reproduzir as etapas de evolução econômica dos países desenvolvidos, mesmo que sem o sucesso alcançado por estes (LIPIETZ, 1987). O modelo desenvolvimentista 
reproduzido durante as décadas de 60 e 70 atingiu o seu limite no início da década de 80 , em virtude de algumas consequências de sua implementação no país, dentre elas, a ampliação da desigualdade social; a dependência grande das importações de petróleo; a inflação crônica e crescente; e o grande endividamento interno e externo foram as que mais afetaram a imagem do progresso que se tinha construído nos primeiros anos de ditadura militar (BECKER \& EGLER, 1994). Além disso, as demandas pela reabertura democrática do país e pela descentralização do poder foram importantes para a dissolução do regime militar e pela proposição de modelos alternativos de desenvolvimento no contexto nacional.

As políticas de turismo, bem como outras políticas setoriais, foram afetadas da mesma forma pelos modelos de desenvolvimento do país nos dois períodos assinalados. Por isso podemos afirmar que existem na atualidade dois modelos de planejamento e territorialização do turismo: um primeiro modelo influenciado pela lógica desenvolvimentista, exploratória e dos grandes projetos, ainda em voga em planos de grande obras turísticas; e um outro modelo que se apoia nas premissas do desenvolvimento sustentável, de apelo local e com tendência à descentralização e menor controle estatal sobre os processos socioespaciais (CRUZ, 2006).

No primeiro modelo, pensado em relação ao turismo, podemos dizer que houve uma estratégia de segmentação da oferta e a construção de um modelo aplicável ao país como um todo, no qual o Estado tentou dotar algumas localidades de infraestruturas básicas (mormente, rodovias e planos de urbanização dos centros) que serviriam de sustentáculo ao modelo de turismo urbano. O Projeto TURIS, por exemplo, repercutiu as iniciativas da Embratur em pensar o turismo no território nacional ao selecionar áreas destinadas a públicos determinados ao longo da costa brasileira nos anos 1970. Angra dos Reis foi direcionada a um público de classe $A$, ou seja, de alta renda. Ainda que o projeto não tenha sido implementado, ele serviu como um ideário para os empresários do turismo, que direcionaram os investimentos para a margem arenosa da BR-101 nos anos seguintes. A Costa Verde talvez seja o mais bem-sucedido caso de consolidação de um turismo de elite com viés de autossegregação no país, o que pode ser parcialmente entendido a partir dos condicionantes expostos na primeira parte do artigo.

Este modelo por ter sido extremamente centralizado, por ter explorado os recursos territoriais desordenadamente e por ter ignorado as especificidades locais tornou-se obsoleto - ainda que não esteja extinto - a partir do início da década de 80. Novas inspirações ideológicas de cunho político-ambiental começavam a influenciar as medidas de ação no território, com ênfase em três pilares sociais de implicações territoriais: liberalização econômica, descentralização política e desenvolvimento sustentável. Seriam estes três pilares a base de sustentação do novo modelo que emergiria no início da década de 1990 (BECKER \& MIRANDA, 1997).

A Ilha Grande (figura 8) passou a ser, neste contexto, um laboratório de experiências legais e técnicas de preservação e de conservação da paisagem natural. A manutenção de uma baixa densidade de ocupação 
ao longo do século XX decorreu, dentre outros fatores, pelo seu caráter insular e seu relativo isolamento e dificuldade de acesso. Além disso, as presenças, em um primeiro momento de um centro de triagem e quarentena e, depois, de um presídio, trouxeram ainda novos fatores limitadores para a sua ocupação até o fim da década de 1980. Há certo consenso sobre estes fatores e sobre a afirmação de que a territorialização do turismo é um processo iniciado, de fato, nos anos 1990 (PRADO, 2006), mesmo que as primeiras pousadas e atividades de turismo já sejam relatadas na década de 1970. Na época, cerca de 8 mil pessoas viviam na ilha e existiam já dois hotéis nas cerca de 76 praias em péssimas condições de habitabilidade. Ainda assim, a maior parte dos habitantes vivia da pesca, especialmente da sardinha, que se concentrava em uma dezena de indústrias de beneficiamento de pescado (O Globo, 23 de Abril de 1976).

Figura 8: Foto panorâmica da enseada do Abraão, na Ilha Grande. Fonte: autor, 2010

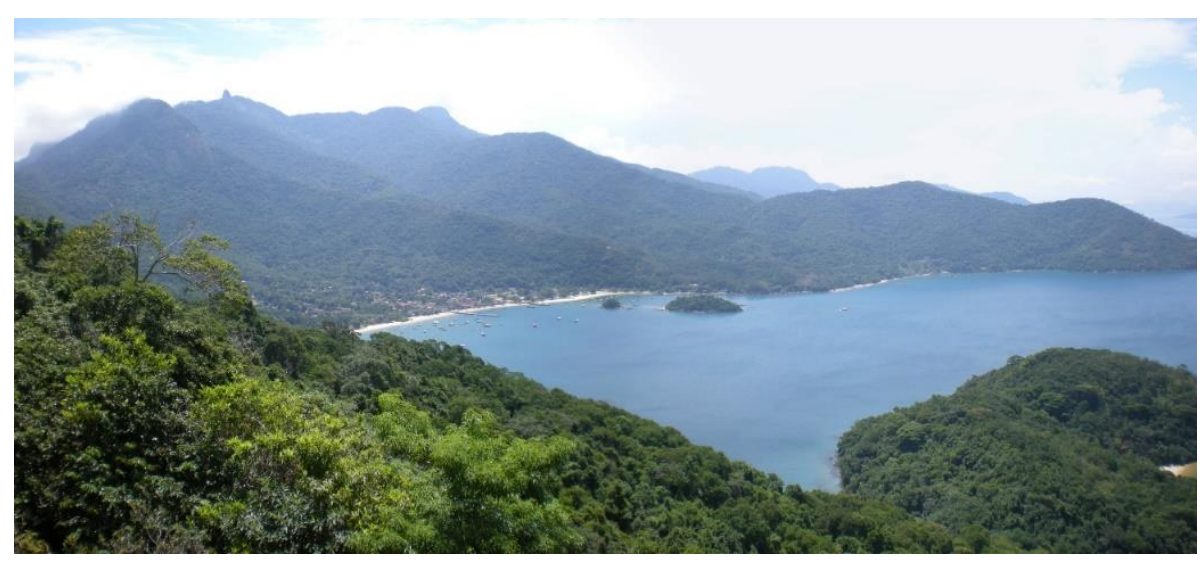

Ao longo dos anos 1970, 80 e 90 a ilha foi submetida a um contínuo processo de mapeamento, observação científica e triagem ecológica, resultando em uma sobreposição de marcos legais de preservação e na quase total absorção do território por unidades de conservação (figura 9). Em alguns casos, as novas medidas legais se impuseram às práticas tradicionais da população caiçara, resultando em conflitos entre modelos de produção e de preservação do ambiente vivido. Processo ainda em andamento e fruto de intensos debates locais. A situação atual incorpora quase uma dezena de decretos e resoluções que buscam preservar a ilha do uso predatório, se sobrepõem a Área de Proteção Ambiental de Tamoios, a sua definição como Patrimônio Nacional (e agora internacional), a sua presença como Reserva da Biosfera da Mata Atlântica, como Reserva Biológica e como Parque Estadual. 
Figura 9: Mapa do território das unidades de conservação para o município de Angra dos Reis. Fonte: elaboração própria.

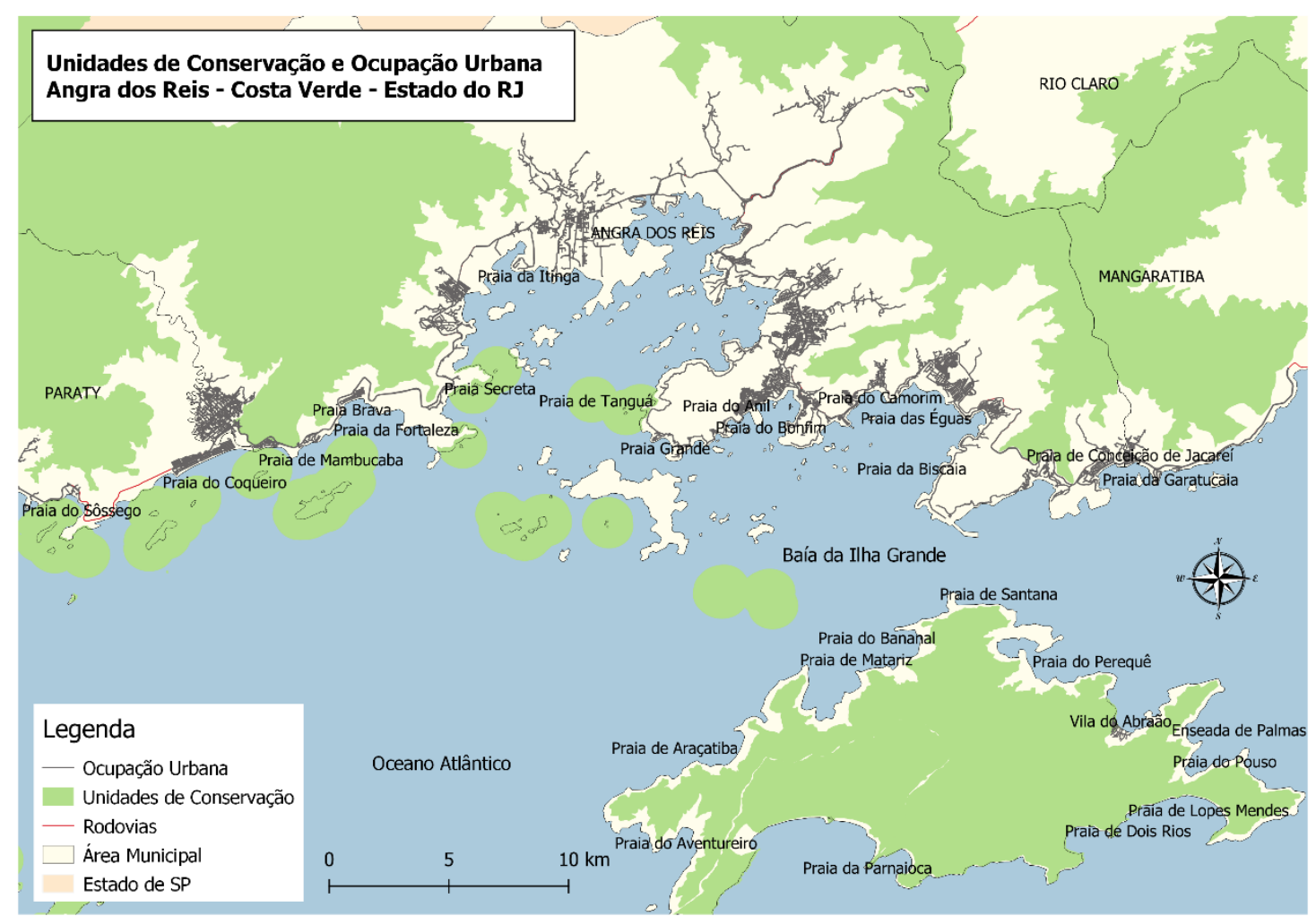

Apesar das iniciativas de preservação e de controle dos acessos, a llha Grande é um espaço bastante heterogêneo em termos da sua ocupação. As habitações dos moradores e as pousadas de pequeno porte ao longo da área do Abraão contrastam com as mansões, vilas de pescadores e praias desertas. Padrões construtivos do tipo condomínio podem ser observadas em algumas praias, remetendo, inclusive, a uma paisagem mais próxima dos resorts encontrados no continente (figura 10). Ocupações mais densas, como a do Abraão, lembram em sua arquitetura e no conjunto urbano as feições das praias populares de Angra dos Reis. Isto nos ajuda a pensar e rever os próprios tipos ideais estudados nos últimos dez anos. Há enclaves que podem ser encontrados mesmo quando não estão associados aos resorts e condomínios. No limite, os parques e as unidades de conservação podem também ser enclaves territoriais, visto que segmentam o uso e orientam as formas de ocupação (e segregação) no espaço, ainda que sob outro conjunto de fatores socioespaciais. 
Figura 10: Foto de uma casa no condomínio PortoBello, em Mangaratiba, como exemplo da arquitetura de luxo presente nos resorts da região. Fonte: autor, 2019

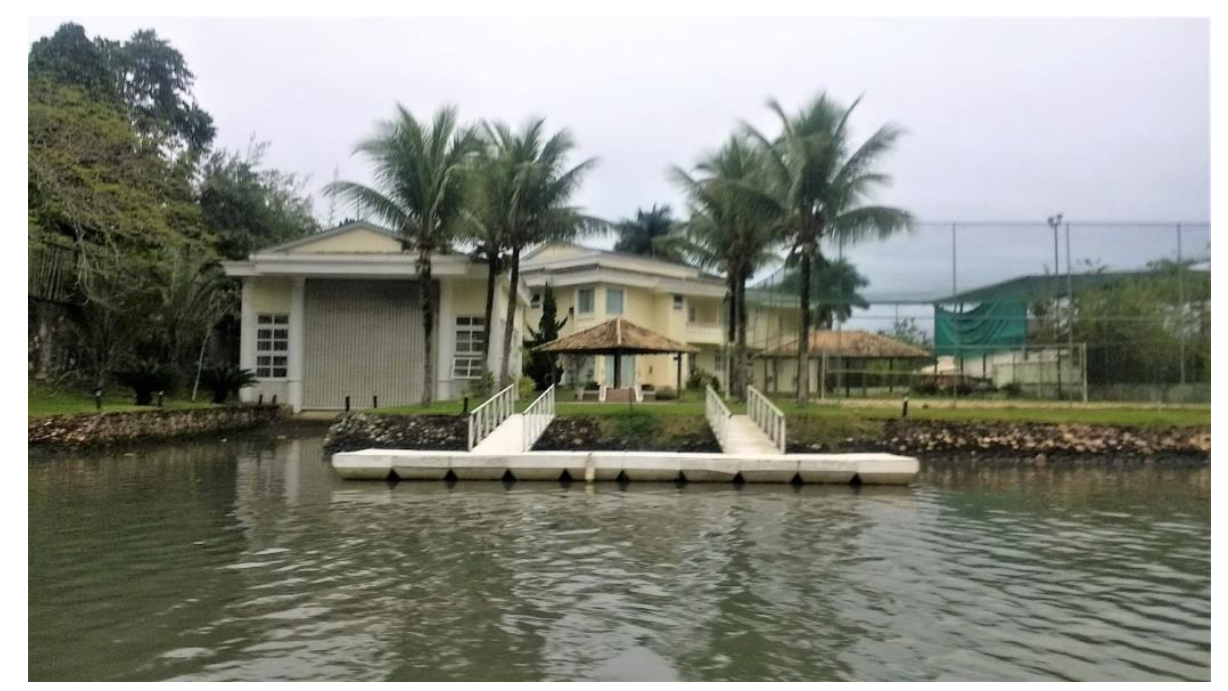

A praia talvez seja o bem público de maior valor para o turismo em Angra dos Reis. Nos Planos Diretores de 1991 e de 2006 a praia é considerada bem público de uso comum do povo e, em razão disso, o acesso é garantido pelas leis municipais e em respeito à legislação ambiental federal. A preservação do meio ambiente é colocada, assim, na interface entre os usos sociais e o direito público, prevalecendo a ideia de contenção dos impactos ambientais advindos da interferência de agentes privados. A Lei de Uso e Ocupação do Solo retoma em vários momentos a necessidade de preservar áreas livres para a manutenção da composição da paisagem urbana e natural, bem como de espaços de observação, como mirantes, para a apreciação da paisagem. Vias e logradouros públicos devem receber tratamento paisagístico para compor a paisagem e motivar a prática de atividades ao ar livre. Nesse caso, os instrumentos visam criar também uma ambiência para que os cidadãos possam permanecer nos espaços e admirar a paisagem, o que reflete as mudanças na gestão do turismo e do território a partir dos anos 1980 (GÓIS, 2018).

É importante salientar que o turismo é um tema caro para o município, muito embora a conexão com os espaços públicos apareça de forma relativamente fraca, devido, entre outros fatores, à história de sua efetivação no município. A Lei de Uso e Ocupação do Solo, por exemplo, apenas delimita as áreas que poderiam receber a infraestrutura turística, ressaltando o fato de que o caráter público de algumas áreas, como as praias, deve ser considerado. O Código Ambiental do Município reforça a questão ao salientar que espaços públicos de lazer e áreas verdes deverão ser criados para o benefício da população como contrapartida aos empreendimentos turísticos, incluindo também os cais. Ou seja, dentro da legislação há um claro sentido preservacionista, o que é contrastado pelas ações coordenadas desde a década de 1970 para a implantação dos territórios turísticos. Nesse caso, a Ilha Grande se tornou o elemento territorial central de tal discurso público. 
Os impactos podem ser observados em diversas frentes, implicando em conflitos territoriais e novas lutas dentro da sociedade angrense (RIBEIRO, 2017). O mais evidente é o impacto na estrutura urbana municipal em sua área continental, conformada por ilhas de lazer conectadas pela rodovia BR-101 e entremeadas por aglomerações urbanas densas nas áreas menos valorizadas do município. Este modelo de territorialização do turismo de veraneio em forma insular demanda uma reorganização viária que sustente o deslocamento diário da população de trabalhadores dessas localidades. O efeito prático desse modelo é a quase invisibilidade dos empreendimentos turísticos e uma significativa exposição das ocupações e dos deslocamentos da população de trabalhadores do município e região. Esta invisibilidade do turismo no continente é evidenciada pelo paisagismo e pela arquitetura dos muros, das cercas e das cancelas e se diferencia de forma absoluta do turismo praticado na Ilha Grande, onde tais estratégias encontram maiores empecilhos para serem desenvolvidas.

O fato é que ao cercar grandes trechos do território e estabelecer a sua vigilância, os agentes do turismo (proprietários de terras e construtoras) acabam por privatizar bens públicos e por orientar comportamentos, transformando espaços públicos em territórios sob o domínio exclusivo de um grupo social. Este fato é um contraponto fundamental à legislação municipal, estadual e federal. Torna-se, assim, um objeto da luta local pela justiça social e pelo direito ao uso do território. A paisagem do município revela, portanto, duas formas de ser urbano: uma na qual a ausência e a invisibilidade conformam um território exclusivo; e outra na qual a constante presença e visibilidade atesta os dilemas sociais e materiais da população do município. As políticas territoriais do Estado são peças desse jogo e estão nesse momento sendo reorganizadas no âmbito da política municipal. Caberá aos interessados acompanhar os desdobramentos dessas disputas e seus impactos no cotidiano da população.

\section{APONTAMENTOS FINAIS}

À guisa de reflexões finais, é justo voltar a tocar em três aspectos centrais deste artigo: a territorialização do turismo como processo, a urbanização como forma e o conflito como efeito das intervenções no espaço. Em primeiro lugar, o controle de um setor espacial por dado grupo social converte espaço público em território e fixa normas de comportamento para aqueles que desejam usufruir daquele lugar. Esta delimitação não é instantânea, ela se estabelece ao longo do tempo, resultado de acordos e de imposições que ocorrem em determinados contextos. A territorialização do turismo em Angra dos Reis resultou de um momento político propício e uma flexibilização jurídica vantajosa para a seletividade espacial dos setores espaciais que detinham melhores atrativos paisagísticos. Ainda resta saber o papel de influência que os agentes ligados ao turismo têm hoje sobre o poder legislativo municipal e estadual e como a sua atuação tem reorientado a fiscalização da aplicação dessa legislação. 
Em segundo lugar, a territorialização foi um processo que tomou uma forma específica: o urbano. Isto se desenvolveu de duas maneiras: a partir de adaptações e de criações originais de resorts sobre áreas de restinga e de manguezal, com a construção de mansões, deques, marinas, helipontos, muros, cercas, diques, aterros, postes de energia etc.; e a partir de uma constante demanda por trabalhadores da construção civil, do setor de hotelaria, de auxiliares de serviços gerais e de funcionários para as necessidades de segurança e manutenção das estruturas turísticas. Há uma conta a ser feita: quanto da população municipal trabalha ou trabalhou para os empreendimentos turísticos? Aonde vive essa população? Que implicações essa dinâmica social tem para a cidade e o cotidiano desta população?

Por fim, o caráter conflituoso dessa relação entre as diversas "cidades" dentro do município de Angra dos Reis ainda precisa ser mais claramente delimitado. Nota-se que o processo de territorialização do turismo ocupa de forma diversificada toda a região, tendo um papel central na organização interna dos municípios, o que inclui as formas de deflagração dos conflitos entre as populações. Isto inclui não somente os conflitos entre os agentes no poder, mas os conflitos sociais, ambientais e ideológicos entre as partes. A questão do direito também se impõe ao debate, especialmente em relação ao direito dos povos tradicionais, dos cidadãos e dos trabalhadores. Direitos que passam por uma renovação do contrato social, da aplicação das leis e de um olhar para o futuro, para outros modos de ocupação e de valorização dos territórios dentro dos contextos municipais e regionais.

\section{REFERÊNCIAS}

ALVES FILHO, Deusdedith de Souza. Angra dos Reis: monumentos históricos entre a indústria e o paraíso. 2004. Dissertação (Mestrado em Planejamento Urbano e Regional) - Universidade Federal do Rio de Janeiro, Rio de Janeiro, 2004.

BECKER, Bertha; EGLER, Antônio Claudio. Brasil: uma nova potência regional na economia-mundo. Rio de Janeiro: Bertrand Brasil, 1994.

BECKER, Bertha; MIRANDA, Mariana. A Geografia Política do Desenvolvimento Sustentável. Rio de Janeiro: Editora da UFRJ, 1997.

BERTONCELLO, Rodolfo. Processo de Modernização e Espaço Local: o caso do município de Angra dos Reis (RJ). 1992. Dissertação (Mestrado em Geografia) - Universidade Federal do Rio de Janeiro, Rio de Janeiro, 1992.

BRITTON, Stephen. Tourism, Capital, and Place: towards a critical geography of tourism. Environment and planning D: society and space, v. 9, n. 4, p. 451-478, 1991.

CARA, Roberto Bustos. El Turismo y los Procesos de Transformacion Territorial. In: RODRIGUES, Adyr Balastreri (org.). Turismo e Geografia: reflexões teóricas e enfoques regionais. São Paulo: Hucitec, 1996.

CASTROGIOVANNI, Antônio Carlos. Turismo x Espaço: reflexões necessárias na pós-modernidade. In: GASTAL, Susana; CASTROGIOVANNI, Antônio Carlos. Turismo na Pós-modernidade (Des)inquietações. Porto Alegre: EDIPUCRS, 2003.

COLES, Tim; DUVAL, David Timothy; HALL, C. Michael. Tourism, Mobility, and Global Communities: new approaches to theorising tourism and tourist spaces. In: THEOBALD, William F. (Ed.). Global Tourism. Oxford: Routledge, 2005.

CORIOLANO, Luzia Neide M.T. Turismo: prática social de apropriação e de dominação de territórios. In: LEMOS, A.I.G.; ARROYO, M.; SILVEIRA, M.L. (org.). América Latina: cidade, campo e turismo. São Paulo: Clacso, 2006.

CORRÊA, Roberto Lobato. Trajetórias Geográficas. Rio de Janeiro: Bertrand Brasil, 2005. 
CORRÊA, Renata da Silva. Angra dos Reis: contribuição ao entendimento de uma pretensa vocação turística - pensando o turismo a partir do território. In: ENCONTRO NACIONAL DE GRUPOS DE PESQUISA, 4., 2008, São Paulo. Anais do IV Encontro Nacional de Grupos de Pesquisa, São Paulo, 2008.

CRUZ, Rita de Cássia Ariza. Política de Turismo e Território. São Paulo: Contexto, 2000.

CRUZ, Rita de Cássia Ariza. Planejamento Governamental do Turismo: convergências e contradições na produção do espaço. In: LEMOS, A.I.G.; ARROYO, M.; SILVEIRA, M.L. (org.). América Latina: cidade, campo e turismo. São Paulo: Clacso, 2006.

FONSECA, Maria Aparecida Pontes. Espaço, Políticas de Turismo e Competitividade. Natal: EdUfrn, 2005.

FONSECA, Tiago Boruchovitch; LOPES JUNIOR, Wilson Martins. Estudo do perfil dos turistas que visitam a Ilha Grande a partir do Cais de Santa Luzia, Angra dos Reis - Rio de Janeiro, Brasil. Turismo e Sociedade, v. 9, n. 2, ago. 2016.

GÓIS, Marcos P.F. O Espaço do Público nos Instrumentos de Política Urbana de Angra dos Reis, Rio de Janeiro, Brasil (1988-2016). Revista Caminhos da Geografia, v. 19, n. 66, jun., 2018.

HAESBAERT, Rogério. O mito da desterritorialização: do "fim dos territórios" à multiterritorialidade. Rio de Janeiro: Bertrand Brasil, 2004.

HALL, C. Michael. Reconsidering the Geography of Tourism and Contemporary Mobility. Geographical Research, v. 43, n. 2, p. 125139, 2005.

HALL, C. Michael; PAGE, Stephen J. The Geography of Tourism and Recreation: environment, place and space. Oxford: Routledge, 1999.

KNAFOU, Remy. Turismo e Território. In: RODRIGUES, Adyr Balastreri (org.). Turismo e Geografia: reflexões teóricas e enfoques regionais. São Paulo: Hucitec, 1996.

LANCI DA SILVA, Maria da Glória. Cidades Turísticas identidades e cenários de lazer. São Paulo: Aleph, 2004.

LIPIETZ, Alain. Miragens e Milagres. São Paulo: Editora Nobel, 1987.

LUCHIARI, Maria Tereza Duarte Paes. Urbanização Turística: um novo nexo entre o lugar e o mundo. In: LIMA, Luiz Cruz (org.). Da Cidade ao Campo: a diversidade do saber-fazer turístico. Fortaleza: Uece, 1998.

MACHADO, Lia Osório. Diagnóstico Sócio-Ambiental do Município de Angra dos Reis. Rio de Janeiro: Convênio Furnas-Ufrj, 1995.

MASCARENHAS, Gilmar. Urbanização Turística e a Produção do Lugar em Penedo. In: BARTHOLO, Roberto; DELAMARO, Maurício; BADIN Luciana (org.). Turismo e Sustentabilidade no Estado do Rio de Janeiro. Rio de Janeiro: FAPERJ/Garamond, 2005.

MULLINS, Patrick. Tourism Urbanization. International Journal of Urban and Regional Research, v. 15, n. 3, p. 326-342, 1991.

PARENTE-RIBEIRO, Leticia; GÓIS, Marcos Paulo Ferreira de \& SOTRATTI, Marcelo Antônio. A Balnearização da Baixada de Araruama e a Emergência da "Costa do Sol”, Rio de Janeiro (1940-1960). Revista Confins, Online, n. 39, 2019.

PEARCE, Douglas G. Towards a Geography of Tourism. Annals of Tourism Research, v. 6, n. 3, p. 245-272, 1979.

PRADO, Rosane Manhães (org.). Ilha Grande: do sambaqui ao turismo. Rio de Janeiro: Garamond / Eduerj, 2006.

RIBEIRO, Irene Chada. Contradições entre o Público, o Privado e o Comum: lutas pelo direito à praia contra processos de privatização em Angra dos Reis, RJ. 2017. Dissertação (Mestrado em Geografia) - Universidade Federal Fluminense, Niterói, 2017.

RIBEIRO, Miguel Angelo. Tipologia das Atividades Turísticas: o exemplo do estado do Rio de Janeiro. GeoUerj, Rio de Janeiro, n.13, p.27-37, jan./ jun., 2003.

RODRIGUES, Adyr Balastreri (org.). Turismo e Geografia: reflexões teóricas e enfoques regionais. São Paulo: Hucitec, 1997.

RODRIGUES, Adyr Balastreri. Turismo e Espaço: rumo a um conhecimento transdisciplinar. São Paulo: Hucitec, 1999.

RODRIGUES, Adyr Balastreri. Turismo e Territorialidades Plurais - lógicas excludentes ou solidariedade organizacional. In: LEMOS, A.I.G.; ARROYO, M.; SILVEIRA, M.L. (org.). América Latina: cidade, campo e turismo. São Paulo: Clacso, 2006.

SACK, Robert David. Human territoriality: its theory and history. Cambridge: Cambridge University Press, 1986.

SILVA, Sylvio Bandeira de Mello. Turismo e Urbanização. In: RODRIGUES, Adyr Balastreri (org.). Turismo, Modernidade, Globalização. São Paulo: Hucitec, 1997. 
SINGER, Paul. O Uso do Solo Urbano na Economia Capitalista. In: MARICATO, Erminia (org.). A Produção Capitalista da Casa (e da cidade) no Brasil Industrial. São Paulo: Editora Alfa-Omega, 1979.

STORPER, Michael. Territorialização numa Economia Global: possibilidades de desenvolvimento tecnológico, comercial e regional em economias subdesenvolvidas. In: LAVINAS, Lena; CARLEIAL, Liana Maria da Frota; NABUCO, Maria Regina (org.). Integração, Região e Regionalismo. Rio de Janeiro: Bertrand Brasil, 1994.

TRIGUEIRO, Aline. Utilidade e Natureza: reflexões acerca das representações e práticas ecológico-ambientais em Angra dos Reis/RJ. 2007. Tese (Doutorado em Sociologia) - Universidade Federal do Rio de Janeiro, Rio de Janeiro, 2007.

WILLIAMS, Stephen. Tourism Geography. Londres: Psychology Press, 1998.

WILLIAMS, Stephen; LEW, Alan A. Tourism Geography: critical understandings of place, space and experience. Londres: Routledge, 1998. 